\title{
Adenosarcoma pT3 TNM Finding v7
}

National Cancer Institute

\section{Source}

National Cancer Institute. Adenosarcoma pT3 TNM Finding v7. NCI Thesaurus. Code C89618.

Tumor involves abdominal tissues. (from AJCC 7th Ed.) 